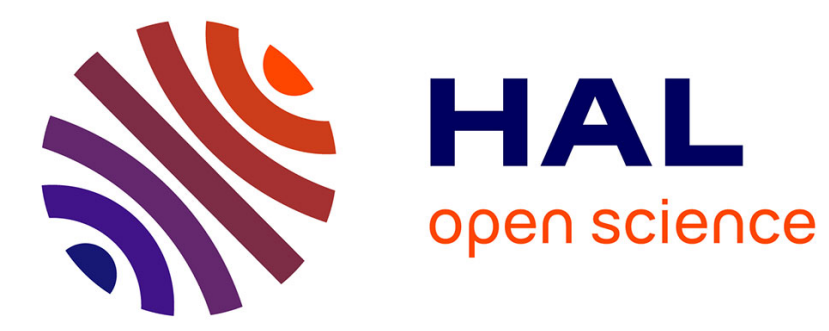

\title{
Understanding Public Value Creation in the Delivery of Electronic Services
}

\author{
Luis F. Luna-Reyes, Rodrigo Sandoval-Almazan, Gabriel Puron-Cid, Sergio \\ Picazo-Vela, Dolores E. Luna, J. Ramon Gil-Garcia
}

\section{- To cite this version:}

Luis F. Luna-Reyes, Rodrigo Sandoval-Almazan, Gabriel Puron-Cid, Sergio Picazo-Vela, Dolores E. Luna, et al.. Understanding Public Value Creation in the Delivery of Electronic Services. 16th International Conference on Electronic Government (EGOV), Sep 2017, St. Petersburg, Russia. pp.378-385, 10.1007/978-3-319-64677-0_31. hal-01702999

\section{HAL Id: hal-01702999 \\ https://hal.inria.fr/hal-01702999}

Submitted on 7 Feb 2018

HAL is a multi-disciplinary open access archive for the deposit and dissemination of scientific research documents, whether they are published or not. The documents may come from teaching and research institutions in France or abroad, or from public or private research centers.
L'archive ouverte pluridisciplinaire HAL, est destinée au dépôt et à la diffusion de documents scientifiques de niveau recherche, publiés ou non, émanant des établissements d'enseignement et de recherche français ou étrangers, des laboratoires publics ou privés.

\section{(c)(1)}

Distributed under a Creative Commons Attribution| 4.0 International License 


\title{
Understanding Public Value Creation in the Delivery of Electronic Services
}

\author{
Luis F. Luna-Reyes ${ }^{1[0000-0002-0852-404 X]}$, Rodrigo Sandoval-Almazan [20000-0002-7864-6464], \\ Gabriel Puron-Cid ${ }^{3[0000-0002-6272-7374]}$, Sergio Picazo-Vela ${ }^{4[0000-0003-3774-3492]}$, Dolores E. \\ Luna $^{4[0000-0002-0601-5006]}$ and J. Ramon Gil-Garcia ${ }^{10000-0002-1033-4974]}$ \\ ${ }^{1}$ University at Albany, State University of New York, Albany NY 12222, USA \\ ${ }^{2}$ Universidad Autonoma del Estado de Mexico, Toluca EdoMex 50130, Mexico \\ ${ }^{3}$ Centro de Investigacion y Docencia Economicas, Aguascalientes Ags 20313, Mexico \\ ${ }^{4}$ Universidad de las Americas Puebla, Cholula Pue 72810, Mexico \\ lluna-reyes@albany.edu
}

\begin{abstract}
Understanding public value creation through electronic services is a complex and important research problem. Recent attempts to understand electronic services value from the citizen perspective suggest that dividing service delivery in several stages could be a valuable approach to understand ways in which information technologies support value creation when providing electronic services. Therefore, we propose the use of this process model as a tool to analyze and define public value creation through electronic services. We show the potential value of the model using birth certificate requests as a hypothetical example. We conclude the paper by describing how we are applying the model to our current research.
\end{abstract}

Keywords: Public Value, Electronic Services, Digital Government, Citizen Behavior Model, Electronic Government.

\section{Introduction}

The concept of public value has become increasingly important in the field of digital government, public administration, and a few other related disciplines. However, in spite of some efforts to clarify the concept and its implications for digital government research [1], public value is not yet clearly defined. In fact, there is not a clear agreement on the definition of Public Value even among Public Value scholars [2]. On the other hand, conducting some preliminary focus groups related to the use of digital government services, one of the main problems identified by the researchers was the difficulty of framing the creation of value in the conversation with focus groups participants [3].

In this way, we propose in this paper a process model that may serve as a framework to understand public value creation in the delivery of electronic services. The model is an adaptation from consumer behavior models developed in the field of marketing, and commonly used in electronic commerce applications [4-6]. We believe that this process model provides a framework to think about public value creation in a 
more operational way, making easier to connect specific technology-supported processes with the creation of values to the public.

The rest of the paper is organized in three sections. The second section includes preliminary conceptual ideas associated to public value and the process model. Section three introduces a conceptual analysis of the potential use of the model to understand public value creation. We finish the paper with a reflection on the potential use of the model, and the ways in which we are using it in our current research.

\section{A Framework for Public Value Creation in Electronic Services}

The present section is an introduction to the main concepts in public value creation and also includes a brief presentation of our preliminary process model. The model was developed by the authors as part of a project in which we are looking to better understand the creation of public value in electronic services from the citizen perspective. The model is a way of connecting the use of electronic services to the creation of public value.

\subsection{Approaches to Public Value}

Information technologies in government have played an important role in government modernization agendas [7, 8]. The use of technology has always been associated with value creation. In the early days of information technology use in government, efficiencies and cost savings were the most important sources of value [9]. The New Public Management and collaborative governance approaches have emphasized on applications looking beyond the organizational boundaries of government, adding focus on program effectiveness, citizen participation and improved democracy $[9,10]$.

Digital government creates value by applying information technologies in support of core government tasks and public service delivery. Public value management has been recently identified as an approach to public administration that is still in the process of being defined [2]. Although there are competing definitions, in this paper we are understanding public value creation as an strategic approach to public management [11]. This approach to public management was proposed by Moore [12], who introduced the concept as a way to understand the creation of value by public managers in contrast to the approach to value in the private sector, where the emphasis is in the creation of value for the stockholders. In the public sector, as a contrast, value is to be created for the public. According to him, value creation was the result of aligning three interrelated processes in a strategic triangle [11]: (1) defining public value, (2) building and sustaining a group of diverse stakeholders to create an authorizing environment, and (3) mobilizing the resources from inside and outside the organization to achieve the desired outcomes.

Parallel developments have been more focused on defining value to the public. In the area of digital government, for example, public value has been defined as the result of seven value generators $[13,14]$. These seven generators include efficiency, 
efficacy, enablement, intrinsic enhancements in government actions, transparency, participation, and collaboration. This work emphasizes the multiple and diverse stakeholders that would be involved in any in-depth analysis of an initiative designed to create public value.

In the broader Public Administration literature, Jørgensen and Bozeman have defined seven constellations of values [15]. The constellations involve lists of values such as the ones mentioned above, but organized from the perspective of public administration and its relationships with inside and outside actors. For example, efficiency and effectiveness belong to the constellation of intraorganizational aspects of public administration. Transparency and collaboration, on the other hand, related to the constellation of relationships between public administration and its environment. Other constellations include relationships between public administration and the citizens, politicians and the society at large.

\subsection{A Process Model for Government Electronic Services Delivery}

In an effort to better understand consumers buying decision process, marketers have developed process models that start with identifying a need or problem, and continue with acquiring information about potential solutions, assessing the alternatives, buying, and finally, assessing the results of the product acquired [4-6]. This type of models have been evolving by recognizing that consumers use traditional and on-line channels in different steps of the buying decision process [16].This models have been useful in the design of e-commerce websites and defining conversion goals, which involve developing strategies to promote consumers to move from one step to the next in the buying process, such as requesting for a quote, moving a product to a shopping cart or buying it.

We argue that the use of an adaptation of this type of process models can help to understand information technology value creation through electronic services in government. The idea was derived from our efforts on understanding electronic services public value creation from the citizen perspective. Focus groups with citizens revealed the difficulty on eliciting the public value creation from citizens' perspective. Our adaptation of consumer behavior models includes five stages: Information search, form preparation, submitting forms, payment, and getting results (see Figure 1).

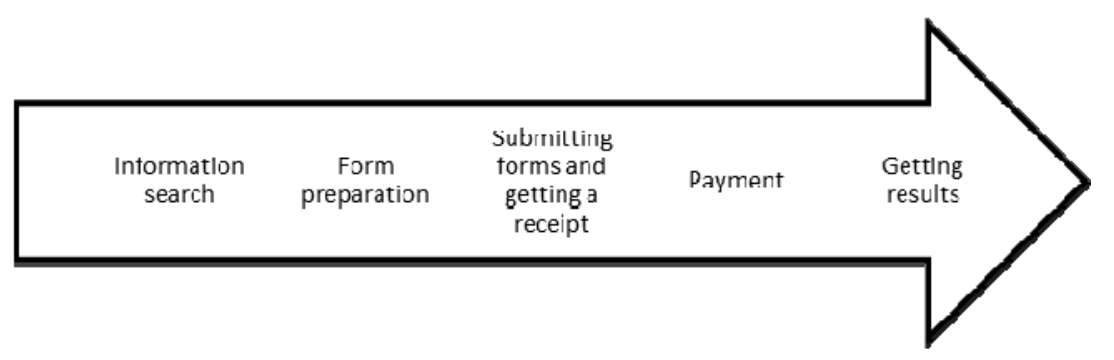

Fig. 1. Citizen Behavior Model. Source: Adapted from [4]. 
Information search involves citizen behavior oriented to find the requirements, costs and documentation of specific services provided by government. Important information for the citizens also includes addresses of public offices where they can apply for the services as well as their hours of operation. The second stage involves the preparation of the forms required to apply for the service. Form completion may require data that is not at the citizen's finger tips, and that is our main rationale on separating this stage from the submission of the forms. Submitting the forms constitutes the third step in our service delivery model, which includes processing of the form and usually issuing a receipt. Although not all public services involve a payment, there are some public services that involve a fee, such as applying for a passport, a driver's license or a birth certificate. Finally, many public services involve some result from the process, and this constitutes the last component of our model.

In the following section, we use the case of requesting a copy of a birth certificate as an example to illustrate the use of the model to understand public value creation through electronic service delivery in government.

\section{Exploring the Potential Utility of the Framework: Obtaining Birth Certificates}

In order to show the usefulness of the proposed process to understand public value creation in the delivery of electronic services, we decided to analyze one public service using the five-step process model. First, we described the five stages for the service including also mechanisms in which information technologies can be used to support each stage of the process. Then, we include examples of individual and public values that are created through the use of information technologies and electronic services. We chose obtaining a copy of a birth certificate as the example or case for this section of the paper. The process may differ from country to country. We are using Mexico as the context for this electronic service.

First of all, it is worth to notice that in the Mexican context, issuing copies of birth certificates is a State level service in charge of the State's Civil Registry. The Civil Registry in each state has offices in major cities, sometimes in each municipality, but sometimes only in major urban centers. Before the introduction of electronic records around 10 years ago [17], obtaining a copy of a birth certificate in Mexico and living in a rural area, implied traveling to the city where the citizen had been registered to search for the original book where the birth was registered and made a copy on this basis. The copy was usually hand-written or typed in a form. Finding the record use to take several days. Another important note is that the postal service in Mexico is not reliable enough to support this type of official requests. In this way, a citizen that needed a copy of his or her birth certificate needed to cover costs of travel and other incidentals to obtain it. It is also important to note that in the context of Mexico, a copy of a birth certificate is a common requirement to apply for school, a scholarship, government benefits, or a job. Currently, and after the introduction of electronic records, it is possible to obtain a birth certificate in any office of the Civil Registry using 
a shared database with a unique population registry. When the state regulations include a standard for electronic signatures, it is also possible an electronic birth certificate. This is possible on very few states.

Table 1. Stages in applying for a copy of a birth certificate in Mexico. Source: Authors' own preparation.

\begin{tabular}{|c|c|c|}
\hline $\begin{array}{l}\text { Step in the behav- } \\
\text { ior model }\end{array}$ & $\begin{array}{l}\text { Activity in the context of obtaining } \\
\text { a Birth Certificate }\end{array}$ & $\begin{array}{l}\text { Potential support by information } \\
\text { technologies }\end{array}$ \\
\hline Information search & $\begin{array}{l}\text { The citizen looks for information } \\
\text { about the requirements, fees, } \\
\text { forms, times and places to apply } \\
\text { for and get a birth certificate. }\end{array}$ & $\begin{array}{l}\text { Information technology can be } \\
\text { used to ask for or distribute the } \\
\text { information via telephone, email, } \\
\text { social media, or a web page. Citi- } \\
\text { zens usually combine more than } \\
\text { one of these technologies in their } \\
\text { process of search. }\end{array}$ \\
\hline Form preparation & $\begin{array}{l}\text { Birth certificates require filling a } \\
\text { form with basic information of the } \\
\text { person that is applying for a copy, } \\
\text { including his/her name, place of } \\
\text { birth and date of birth. Additional- } \\
\text { ly, citizens can provide infor- } \\
\text { mation to ease the search such as } \\
\text { their Unique Registry Identifier } \\
\text { (CURP) or currently, a code asso- } \\
\text { ciated directly to the birth registry. }\end{array}$ & $\begin{array}{l}\text { Information technology can be } \\
\text { used to distribute the form (such a } \\
\text { pdf) through email or a web page. } \\
\text { The form itself can be filled online } \\
\text { by the citizen and submitted via the } \\
\text { web page. In some places in Mexi- } \\
\text { co, the Civil Registry Office has a } \\
\text { self-service kiosk where the citi- } \\
\text { zens input the required data to } \\
\text { obtain the birth certificate. }\end{array}$ \\
\hline $\begin{array}{l}\text { Submitting forms } \\
\text { and getting a re- } \\
\text { ceipt }\end{array}$ & $\begin{array}{l}\text { Submitting the form to apply for a } \\
\text { copy of the birth certificate. }\end{array}$ & $\begin{array}{l}\text { The same electronic media used to } \\
\text { distribute the form can be used to } \\
\text { submit the form (email, web pages, } \\
\text { kiosks, etc.). }\end{array}$ \\
\hline Payment & $\begin{array}{l}\text { There is a fee associated to the } \\
\text { service. }\end{array}$ & $\begin{array}{l}\text { Again, credit cards, ATMs and } \\
\text { Internet-based electronic payments } \\
\text { are ways in which technology can } \\
\text { be used to facilitate the transaction. } \\
\text { Several Mexican States also use } \\
\text { networks of convenience stores to } \\
\text { collect payments for government } \\
\text { fees. }\end{array}$ \\
\hline Getting results & $\begin{array}{l}\text { Obtaining a copy of the birth cer- } \\
\text { tificate }\end{array}$ & $\begin{array}{l}\text { In its most basic form, printers } \\
\text { facilitate the copying process. } \\
\text { Moreover, self-service kiosks have } \\
\text { the potential of being also dispens- } \\
\text { ers of documents. In the cases of } \\
\text { states with a regulation for elec- } \\
\text { tronic signatures, the Internet can } \\
\text { also be used to issue an electronic } \\
\text { document. }\end{array}$ \\
\hline
\end{tabular}

Table 1 describes the main tasks related to each of the five stages in our process model as they relate to the application for a copy of a birth certificate in Mexico. Recently, one of the authors of the paper had to obtain copies of his birth certificate. He 
started, as the model suggest, by searching for information about requirements and places to apply for a copy of his birth certificate. Given that he is not living in the place where he was registered, he started by looking in the website of the Civil Registry of the State where he was born. In that particular State, the website only provided limited information and a phone number to ask for the birth certificate. Using the phone, he provided some basic personal information, including name, city of birth, date of birth, date of registration, and he got in exchange a number associated with the registry in the national population registry. Using this number, he could go to the Civil Registry in the city where he lives now and obtain a copy of his birth certificate. He came in person to the office of the Civil Registry in his current home town, and got a copy of the birth certificate in the same day of the application. The payment of the fee was made on site, using his credit card.

The use of the model to understand specific uses of technology in the process of applying for and getting the service, provides a framework to better understand value creation at the individual and collective levels. Table 2 presents preliminary ideas of individual and public value produced by electronic services from the point of view of the citizen. These initial ideas were originated through preliminary focus groups made in the State of Puebla, Mexico. It is important to point out that it is not easy to elicit public values through open-ended interviews. During the focus groups sessions, we found that citizens can articulate easily the individual value produced by a service, but it is harder for them to articulate the value for the society as a collective. It was also challenging for them to identify the value generated in each of the stages as oppose to the electronic service as a whole. In this preliminary exercise, we are supporting our selection of public values on the inventory proposed by Jørgensen, and Bozeman [15].

Table 2. Table captions should be placed above the tables. Source: Authors’ own preparation.

\begin{tabular}{lll}
\hline Heading level & Example & Font size and style \\
\hline Information search & Time and cost savings & Timeliness \\
& Convenience & Accountability \\
& & Equity \\
Form preparation & Convenience & User orientation \\
& & Timeliness \\
& & User orientation \\
Submitting forms and & Time and costs savings & Equity \\
get a receipt & & Timeliness \\
& & User orientation \\
Payment & Security & Equity \\
& Convenience & Timeliness \\
Getting the results & Time and cost savings & User orientation \\
& Convenience & Timeliness \\
& & Equity \\
& & Competitiveness \\
\hline
\end{tabular}




\section{Final Comments}

Our current research involves the use of the process model to understand value creation through electronic services in Mexico. Our final goal in this particular project is to gather data through a citizen survey to understand relationships between system quality, information quality, user satisfaction, system use, individual benefits, and public value (see Figure 2). The research model in its current form is inspired by Delone and McLean's research [18]. Given initial difficulties in eliciting value from citizens, we are using the process model proposed in this paper as a way of unfolding the concept of use, and understand the mechanisms of public value creation.

Currently, we are using the model in a new series of focus groups to refine the concepts and develop the survey instrument. We are planning to conclude the focus groups in the first half of 2017, with the objective of developing the survey instrument during the Summer. We expect that the focus groups data will provide rich information and a better understanding of individual and public value from the citizen perspective.

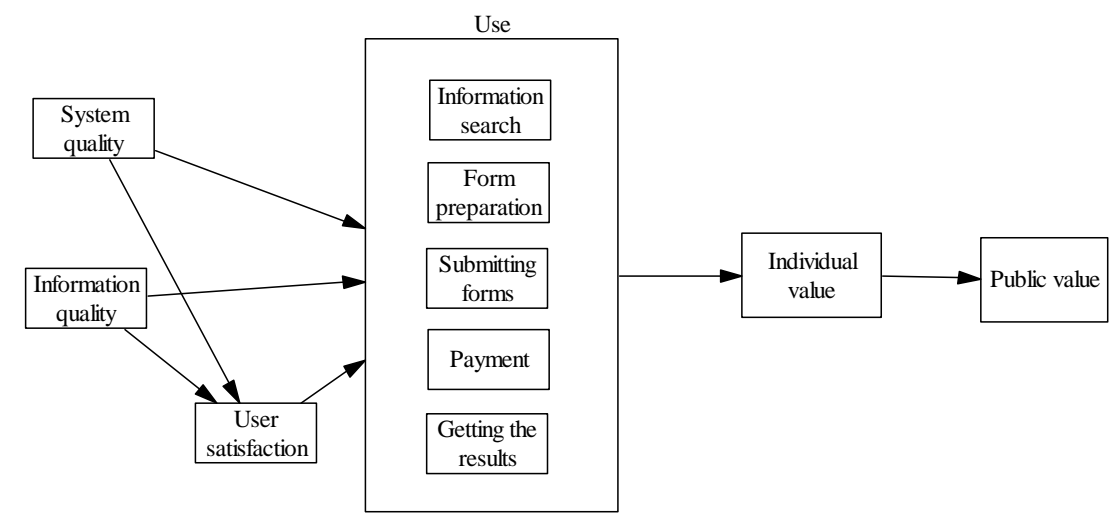

Fig. 2. Research model in current research. Source: Adapted from [4, 18]

\section{References}

1. Cordella, A., Bonina, C.M.: A public value perspective for ICT enabled public sector reforms: A theoretical reflection. Gov. Inf. Q. 29, 512-520 (2012).

2. Bryson, J.M., Crosby, B.C., Bloomberg, L.: Public Value Governance: Moving Beyond Traditional Public Administration and the New Public Management. Public Adm. Rev. n/a-n/a (2014).

3. Luna-Reyes, L.F., Gil-Garcia, J.R., Sandoval-Almazan, R.: Avances y Retos del Gobierno Digital en México. UAEM-IAPEM, Toluca (2015). 
4. Comegys, C., Hannula, M., Väisänen, J.: Longitudinal comparison of Finnish and US online shopping behaviour among university students: The five-stage buying decision process. J. Target. Meas. Anal. Mark. 14, 336-356 (2006).

5. Dewey, J.: How we Think. Cosimo, New York (2007).

6. Engel, J.F., Kollat, D.T., Blackwell: Consumer Behavior. Holt, Rinehart and Winston, Inc, New York (1968).

7. Gil-Garcia, J.R., Arellano-Gault, D., Luna-Reyes, L.F.: Even if we build it, they may not come: Reformas de e-Gobierno en México (2000-2009). In: Valverde Loya, M.A. and Hilderbrand, M. (eds.) ¿Transformación, lo mismo de siempre, o progreso lento y con tropiezos? Reformas recientes al Sector Público en México. pp. 137-171. Graduate School of Public Administration, Instituto Tecnologico de Estudios Superiores de Monterrey-Harvard Kennedy School-Miguel Angel Porrua, Mexico DF (2012).

8. Morgeson, F.V., Mithas, S.: Does E-Government Measure Up to E-Business? Comparing End User Perceptions of U.S. Federal Government and E-Business Web Sites. Public Adm. Rev. 69, 740-752 (2009).

9. Dawes, S.S.: The evolution and continuing challenges of egovernance. Public Adm. Rev. 68, S86-S102 (2008).

10.Clark, B.Y., Brudney, J.L., Jang, S.-G.: Coproduction of Government Services and the New Information Technology: Investigating the Distributional Biases. Public Adm. Rev. 73, 687-701 (2013).

11.Benington, J., Moore, M.H. eds: Public Value: Theory and Practice. Palgrave Macmillan (2010).

12. Moore, M.H.: Creating Public Value: Strategic Management in Government. Harvard University Press, Cambridge, MA (1995).

13.Harrison, T.M., Guerrero, S., Burke, G.B., Cook, M., Cresswell, A., Helbig, N., Hrdinova, J., Pardo, T.: Open government and e-government: Democratic challenges from a public value perspective. Inf. Polity. 17, 83-97 (2012).

14. Cresswell, A.M., Cook, M., Helbig, N.: Putting Public Value to Work: A Framework for Public Management Decision Making. In: Bryson, J., Crosby, B., and Bloomberg, L. (eds.) Public Value and Public Administration. pp. 204-219. Georgetown University Press, Washington, DC (2015).

15.Beck Jørgensen, T., Bozeman, B.: Public Values An Inventory. Adm. Soc. 39, 354-381 (2007).

16.Rippé, C.B., Weisfeld-Spolter, S., Yurova, Y., Sussan, F.: Is there a global multichannel consumer? Int. Mark. Rev. 32, 329-349 (2015).

17.RENAPO: Modernizacion Integral del Registro Civil: Conceptos y Estructura, https://www.renapo.gob.mx/swb/work/models/RENAPO/Resource/317/Conceptos MIRC.pdf, (2005).

18.Delone, W.H., McLean, E.R.: The DeLone and McLean Model of Information Systems Success: A Ten-Year Update. J. Manag. Inf. Syst. 19, 9-30 (2003). 